\title{
Heterogeneous PGE signatures in metasomatic sulfides from the Tallante xenoliths
}

\author{
ERWIN SCHETTINO ${ }^{1 *}$, JOSÉ MARIA GONZÁLEZ-JIMÉNEZ ${ }^{2}$, \\ Claudio MARChESI ${ }^{1,2}$, KAROLY HidAs ${ }^{1}$, CARlOS J. \\ GARRIDO $^{1}$ \\ ${ }^{1}$ Instituto Andaluz de Ciencias de la Tierra (IACT), CSIC- \\ Universidad de Granada, Avenida de las Palmeras s/n, \\ 18100 Granada, Spain (*correspondence: \\ eschettino@correo.ugr.es) \\ ${ }^{2}$ Departamento de Mineralogía y Petrología, Facultad de \\ Ciencias, Universidad de Granada, Avenida Fuentenueva \\ s/n, 18002 Granada, Spain
}

Peridotite mantle xenoliths entrained in Pliocene alkaline volcanic lavas from Tallante (southeast Spain) display a wide range of compositional and mineralogical heterogeneites. The geochemical and mineralogical variability recorded by the Tallante xenoliths documents the extensive transformation of the subcontinental lithospheric mantle in response to the geodynamic evolution of the westernmost Mediterranean. In this contribution, we report a petrographic-geochemical study of base-metal sulfides (BMS) from a set of "anhydrous" lherzolites, in order to unravel the processeses and metasomatic agents governing the mobilization of platinumgroup elements (PGE) in the subcontinental lithospheric mantle.

The BMS assemblage consists of pentlandite \pm chalcopyrite \pm bornite, which are found usually forming composite aggregates hosted in pyroxenes of metasomatic origin. The heterogeneity in geochemical systematics, especially REE, of the sulfide-hosting clinopyroxenes reflects the chromatographic fractionation of an alkaline melt percolating through the mantle wall rocks. Despite their striking homogeneity in texture, major element composition, and microstructural position, sulfides exhibit a wide range of PGE patterns, which cannot be accounted for by crystalchemical partitioning or fractionation of a sulfide melt. Nanoto micro-sized inclusions of PGM are ubiquitous within sulfide grains, suggesting they exerted a strong control on the PGE distribution of the resulting metasomatic BMS. 